\title{
Transinhibition of C1 Inhibitor Synthesis in Type I Hereditary Angioneurotic Edema
}

Judit Kramer, ${ }^{*}$ Fred S. Rosen, ${ }^{*}$ Harvey R. Colten, ${ }^{\star}$ Katalin Rajczy, ${ }^{*}$ and Robert C. Strunk ${ }^{*}$

*Division of Allergy and Pulmonary Medicine, St. Louis Children's Hospital, and the Department of Pediatrics, Washington University School of Medicine, St. Louis, Missouri 63110; and ${ }^{\ddagger}$ Division of Immunology, The Children’s Hospital, Department of Pediatrics, and the Center for Blood Research, Harvard Medical School, Boston, Massachusetts 02115

\begin{abstract}
To ascertain the mechanism for decreased synthesis of $\mathrm{C} 1$ inhibitor ( $\mathrm{C1}$ INH) in certain patients with the autosomal dominant disorder hereditary angioneurotic edema, we studied expression of $\mathrm{Cl}$ INH in fibroblasts in which the mutant and wild type mRNA and protein could be distinguished because of deletion of exon $7\left(\Delta_{E x 7}\right)$. In the HANE $\Delta_{E x 7}$ cells, the amount of wild type mRNA $(2.1 \mathrm{~kb})$ was expressed at $52 \pm 2 \%(n=5)$ of normal, whereas the mutant mRNA was $17 \pm 1 \%(n=5)$ of normal. Rates of synthesis of both wild type and mutant proteins (11 \pm 3 and $3 \pm 1 \%$ of normal, respectively) were lower than predicted from the mRNA levels. There was no evidence of increased $\mathrm{Cl}$ INH protein catabolism. These data indicate that there are multiple levels of control of $\mathrm{C} 1$ INH synthesis in type I hereditary angioneurotic edema. Pretranslational regulation results in $<50 \%$ of the mutant truncated 1.9-kb mRNA. In addition, translational regulation results in decreased synthesis of both wild type and mutant $\mathrm{C} 1$ INH proteins. These data suggest a transinhibition of wild type C1 INH translation by mutant mRNA and/or protein. (J. Clin. Invest. 1993.91:1258-1262.) Key words: hereditary angioneurotic edema $\bullet \mathrm{C} 1$ inhibitor $\bullet$ synthesis • translation • transinhibition
\end{abstract}

\section{Introduction}

Examples in which the products of a eukaryotic gene effect translational regulation of its expression have been recognized in only a few instances $(1,2)$. For example, a recent study $\mathrm{Chu}$ et al. showed that thymidylate synthase protein inhibits translation of thymidylate synthase mRNA without affecting the translation of other mRNA species (2). While several different mechanisms account for the decreased net synthesis of a specific protein in several genetic deficiencies (3), transinhibition of normal gene expression by products of the mutant allele has not yet been reported.

Address correspondence to Robert C. Strunk, Department of Pediatrics, Washington University School of Medicine, $400 \mathrm{~S}$. Kingshighway Blvd., St. Louis, MO 63110. J. Kramer's permanent address is National Institute of Haematology and Blood Transfusion, Department of Immunopathology, PO Box 44, H-1502 Budapest, Hungary. K. Rajczy's permanent address is Gerentology Center, Semmelweis Medical University, PO Box 45, H-1428 Budapest, Hungary.

Received for publication 24 June 1992 and in revised form 8 October 1992.

J. Clin. Invest.

(C) The American Society for Clinical Investigation, Inc.

0021-9738/93/03/1258/05 \$2.00

Volume 91, March 1993, 1258-1262
Hereditary angioneurotic edema (HANE) ${ }^{1}$ is an autosomal dominant disorder caused by a deficiency of the inhibitor of the first component of complement (C1 INH) (4). Two types of HANE have been recognized: type $I$, with low serum concentrations of functionally active $\mathrm{Cl}$ INH protein, and type II, with normal to increased concentrations of a dysfunctional $\mathrm{Cl}$ INH protein (5). The serum of HANE patients contains wild type, functionally active $\mathrm{C} 1$ INH protein at concentrations between 5 and $30 \%$ of normal, instead of the $50 \%$ expected if the single normal allele were fully expressed (4). This discrepancy between the expected and observed levels of $\mathrm{C} 1$ INH protein in HANE has been explained from in vivo studies in HANE patients in which an increased fractional catabolic rate of $\mathrm{Cl}$ INH was measured, and a decreased rate of synthesis of $\mathrm{Cl}$ INH protein was calculated $(6,7)$. Previous studies of $\mathrm{C} 1$ INH biosynthesis in cell culture demonstrated that type I HANE cells synthesized only $20 \%$ of normal amounts of C1 INH (8), similar to the rate of synthesis calculated from the in vivo turnover studies (6). These studies, however, were not able to ascertain separately the products of mutant and wild type genes. Ease of identification of wild type and mutant $\mathrm{Cl}$ INH mRNAs/proteins in cells from a type I HANE kindred in which exon 7 of the $\mathrm{Cl}$ INH gene is deleted $\left(\Delta_{\mathrm{Ex} 7}\right)(9-11)$ make it possible to separately estimate rates of translation of the wild type and mutant alleles.

\section{Methods}

Patient cells. Normal human adult skin fibroblast lines were obtained from human genetic mutant cells, National Institute of General Medical Sciences (Camden, NJ), or were propagated in our laboratory by standard techniques. A fibroblast line was also started from a skin biopsy obtained from a subject type I HANE caused by deletion of exon 7 of the $\mathrm{Cl}$ INH gene $\left(\Delta_{\mathrm{Ex} 7}\right)$. Fibroblast lines from the other HANE patients, four with type I HANE (three females and one male from four different kindred) and three with type II (one individual from the Ta kindred and two individuals of We kindred), have been studied previously (8). In these two type II kindreds, the mutant mRNA was the same mass as the wild type mRNA in Northern blot analysis (8). However, in each kindred, the mutant intracellular $\mathrm{Cl}$ INH protein is $2-3 \mathrm{kD}$ larger than the wild type protein $(8)$. For one of these mutant proteins, the mutation (deletion of Lys 251 ) adds a glycosylation site that yields the change in apparent molecular mass, without altering the primary translation product (12). For the other mutant protein, the mutation (a P14 hinge region mutation from Val to Glu) increases the apparent mass of the primary translation product (13). Cells from passages 4-8 were used in all experiments.

DME (low endotoxin) FBS (endotoxin $<0.01 \mathrm{ng} / \mathrm{ml}$ ), and DME

1. Abbreviations used in this paper: $\mathrm{C} 1 \mathrm{INH}, \mathrm{C} 1$ inhibitor; $\Delta_{\mathrm{Ex} 7}$, deletion of exon 7; HANE, hereditary angioneurotic edema. 
without methionine were purchased from Gibco Laboratories (Grand Island, NY) and penicillin-streptomycin solution and L-glutamine from Flow Laboratories, Inc. (McLean, VA). BSA, fraction V (low endotoxin), was purchased from Sigma Chemical Co. (St. Louis, MO). $\mathrm{L}\left[{ }^{35} \mathrm{~S}\right]$ methionine ( specific activity $\sim 1,000 \mathrm{Ci} / \mathrm{mmol}$ ) was purchased from ICN Radiochemicals (Irvine, CA) and EN ${ }^{3} \mathrm{HANCE}$ was purchased from New England Nuclear (Boston, MA). Goat antibodies to human $\mathrm{Cl}$ INH, $\mathrm{Cl}$, factor $\mathrm{B}$, factor $\mathrm{H}$, and $\mathrm{C} 3$ were purchased from Atlantic Antibodies (Scarborough, ME) and to human C1s were purchased from Cytotech (now part of Quidel, San Diego, CA). Formalin-fixed Staphylococcus aureus (Immunoprecipitin) was purchased from the BRL Life Technologies, Inc. (Gaithersburg, MD). PMSF was purchased from Sigma Chemical Co. (St. Louis, MO) and leupeptin from Calbiochem (La Jolla, CA).

Cell culture and analysis of protein synthesis. Human fibroblasts were grown to confluency in multiwell tissue culture plates in medium containing $10 \%$ FBS and then washed to remove serum and spent medium. The cells were labeled biosynthetically immediately after removal of the FBS. Biosynthetic labeling was performed by incubating the cells in methionine-free DME containing $250 \mu \mathrm{Ci} / \mathrm{ml}\left[{ }^{35} \mathrm{~S}\right]-$ methionine (14) for $60 \mathrm{~min}$, since there was no or only minimal secretion of newly synthesized proteins during this period. The number of cells adherent at confluency in each $16-\mathrm{mm}$ diameter well was 9.78 $\times 10^{4} \pm 0.38($ mean $\pm S D)$ and did not vary with the type of cells. At the end of the pulse period, cells were rinsed and either lysed by freeze thawing as previously described (14), or in pulse-chase experiments, medium containing $\sim 1,000$-fold excess of cold methionine (DME containing $10 \%$ FBS ) was added and the cells were incubated for varying time periods (chase periods). After chase periods, medium was removed, and the cells were washed with ice-cold HBSS before lysis. Cell lysates and extracellular media were prepared for immunoprecipitation by adding PMSF and leupeptin as enzyme inhibitors and detergents, preabsorbed and then immunoprecipitated with monospecific antibodies using formalin-fixed $S$. aureus (14). Immunoprecipitates were subjected to SDS-PAGE under reducing conditions, and the gels were fixed, impregnated with $\mathrm{EN}^{3} \mathrm{HANCE}$, dried, and exposed at $-70^{\circ} \mathrm{C}$ to film (XAR-5; Kodak, Rochester, NY). Total protein synthesis was estimated by incorporation of $\left[{ }^{35} \mathrm{~S}\right]$ methionine into TCA-insoluble protein (14). Incorporation of $\left[{ }^{35} \mathrm{~S}\right]$ methionine into individually immunoprecipitated proteins was determined by subtracting the appropriate background from the counts in the portion of the gel slices containing the protein after digestion with $15 \%$ hydrogen peroxide for $16 \mathrm{~h}$ at $65^{\circ} \mathrm{C}$ and addition of Bio-Safe II (Research Products International Corp., Mount Prospect, IL). Background counts were obtained in another portion of the appropriate lane of the gel not containing protein. If necessary, the amounts of protein were corrected on the basis of TCA-insoluble protein, as described previously (8).

$R N A$ analysis. Total cellular RNA was extracted from fibroblast monolayers by lysis with guanidinium thiocyanate and isolated by cesium chloride density gradient ultracentrifugation, as described previously (8). The amount of total cellular RNA recovered was quantitated by absorbance at $260 \mathrm{~nm}$, and was similar for the normal and HANE $\Delta_{\mathrm{Ex} 7}$ cell. $10 \mu \mathrm{g}$ total cellular RNA was subjected to RNA blot analysis using a riboprobe for $\mathrm{Cl}$ INH ( 368 bp representing the Bgl II to PvulI portion of the cDNA containing the 3 ' end of exon IV and all of exons $\mathrm{V}$ and $\mathrm{VI}$ inserted into the $\mathrm{pSp} 72$ vector). The riboprobe was ${ }^{32} \mathrm{P}$-radiolabeled by using a transcription kit (SP6/T7; Boehringer Mannheim Biochemicals, Indianapolis, IN). C3 and factor B cDNA probes were radiolabeled by random priming (Random Priming Kit; Boehringer Mannheim). The filters were washed and exposed to $\mathrm{x}$-ray film for autoradiography.

\section{Results}

HANE $\Delta_{E x 7}$ fibroblasts synthesize reduced amounts of wild type, as well as mutant $C 1$ INH proteins. $\mathrm{C} 1 \mathrm{INH}$ protein synthesis in skin fibroblasts from normal and HANE $\Delta_{\mathrm{Ex} 7}$ was assessed by SDS-PAGE of $\left[{ }^{35} \mathrm{~S}\right]$ methionine labeled protein. Intracellular lysates of normal cells contained $\mathrm{Cl}$ INH proteins of 78 and $104 \mathrm{kD}$, representing the partially glycosylated primary synthesis product and the fully glycosylated protein, respectively (Fig. 1). In HANE $\Delta_{\mathrm{Ex} 7}$ cells, an additional $66 \mathrm{kD} \mathrm{C1}$ INH protein was detected (Fig. 1). Amounts of mutant (66 $\left.\mathrm{kD}, \Delta_{\mathrm{Ex} 7}\right)$ and wild type $(78 \mathrm{kD}) \mathrm{Cl} \mathrm{INH}$ proteins were $3 \pm 1 \%$ and $11 \pm 3 \%$ of normal, respectively $(n=6)$. Synthesis of other complement proteins, $\mathrm{Cl}$ r, C1s, factor $\mathrm{B}, \mathrm{C} 3$, and factor $\mathrm{H}$, was comparable or greater in the HANE $\Delta_{\mathrm{Ex} 7}$ than in the normal cells, indicating that reduction in synthesis of the $\mathrm{Cl}$ INH proteins was specific. Extracellular media of both normal and HANE $\Delta_{\mathrm{Ex} 7}$ cells contained only a C1 INH protein of $104 \mathrm{kD}$ (Fig. 1). No protein comparable to the expected mass of the glycosylated form of the mutant protein $(\sim 92 \mathrm{kD})$ was identified in the extracellular medium, even with prolonged exposure of the SDS-PAGE gel to the $x$-ray film. In a pulse-chase experiment (Fig. 2), the rate of disappearance of wild type $\mathrm{Cl}$ INH protein was identical in normal and HANE $\Delta_{\mathrm{Ex} 7}$ cells (Fig. $2 B$ ); for each cell type, the amount of wild type $\mathrm{Cl}$ INH protein recovered in the extracellular medium was $\sim 100 \%$ of the amount of wild type protein synthesized during the 1-h pulse period (Fig. $2 C$ ).

To further investigate the fate of the mutant protein, cells were treated with tunicamycin, $5 \mu \mathrm{g} / \mathrm{ml}$, during a 2-h pulse period (Fig. 3). These conditions allowed detection of four forms of $\mathrm{Cl}$ INH in the normal cell lysates, the $53-\mathrm{kD}$ primary translation product, and partially glycosylated forms of 60,66 , and $78 \mathrm{kD}$. HANE $\Delta_{\mathrm{Ex} 7}$ cells contained these four forms, but also had a $45-\mathrm{kD}$ form representing the primary translation product of the mutant protein. The apparent molecular masses of these primary translation products were confirmed by SDSPAGE analyses of proteins translated from fibroblast RNA under cell-free conditions (data not shown); the mutant protein is truncated both because of deletion of exon 7 (nucleotides 1065-1284) and a premature stop codon at nucleotide 1323 (9-11). In the extracellular media, tunicamycin treatment yielded the normal $104-\mathrm{kD}$ protein and a $78-\mathrm{kD}$ form, similar to the major form of the protein in the intracellular lysates, for both the normal and HANE $\Delta_{\mathrm{Ex} 7}$ cells. Taken together, these data suggest that the truncated protein is not secreted from the cell in a stable form.

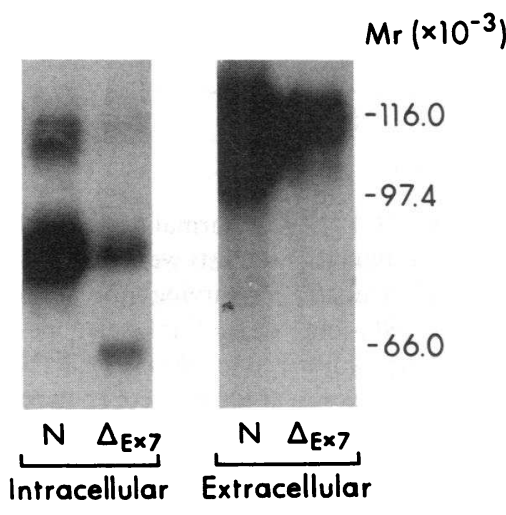

Figure 1. Synthesis of $\mathrm{Cl}$ INH proteins in normal and HANE $\Delta_{\mathrm{Ex} 7}$ fibroblasts. Normal adult human skin fibroblasts and fibroblasts from the patient with HANE $\Delta_{\mathrm{Ex} 7}$ were grown to confluency. Newly synthesized $\mathrm{Cl}$ INH proteins were labeled with $\left[{ }^{35} \mathrm{~S}\right]$ methionine for $2 \mathrm{~h}$, immunoprecipitated with monospecific antibody to $\mathrm{Cl}$

INH using formalin-fixed $S$. aureus, and subjected to SDS-PAGE under reducing conditions (see Methods). In some experiments, an $\sim 92-\mathrm{kD}$ presumed breakdown product of normal $\mathrm{Cl} \mathrm{INH}$ is present in the extracellular medium (not shown here). 

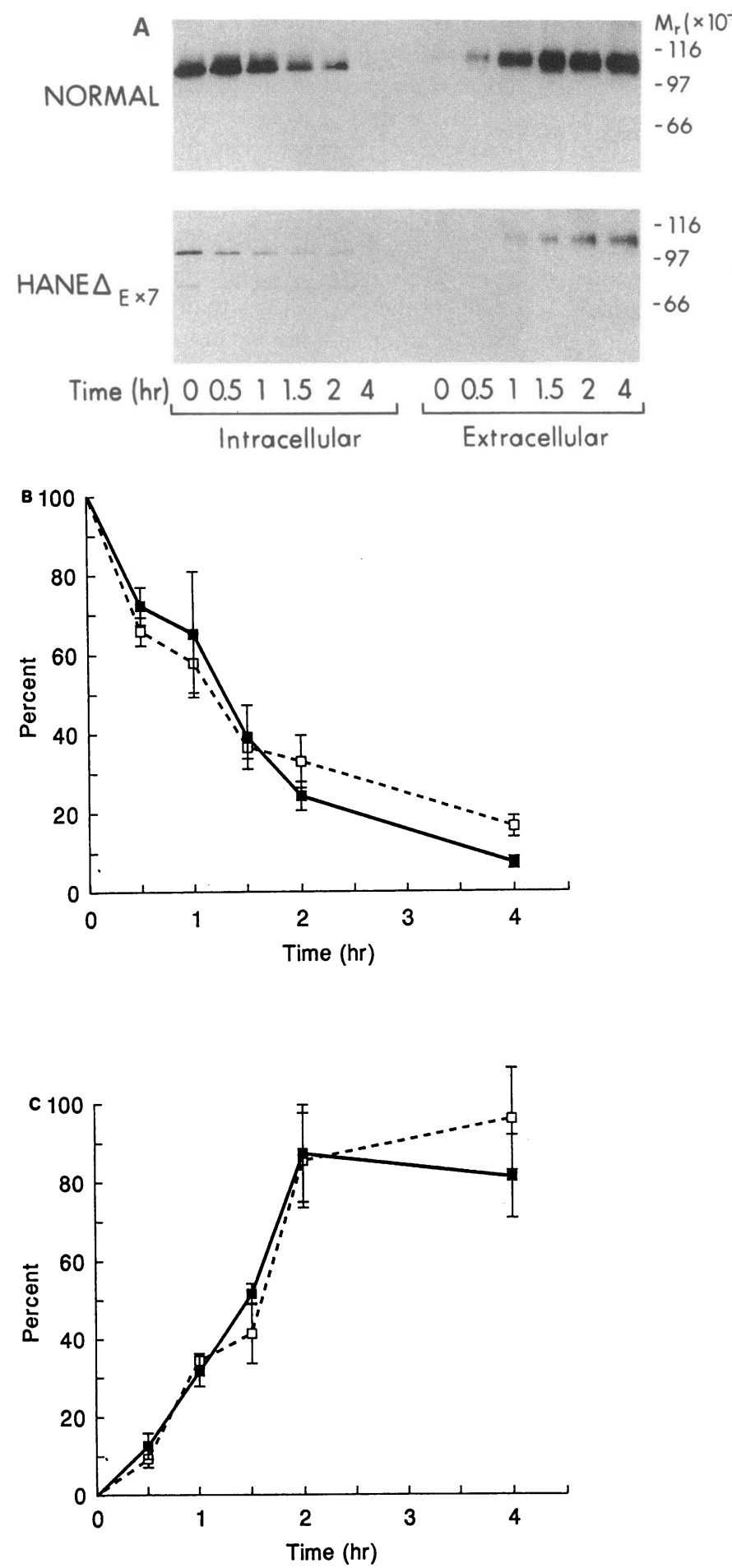

Figure 2. Synthesis and secretion of $\mathrm{Cl}$ INH in normal and HANE $\Delta_{\mathrm{Ex} 7}$ fibroblasts: pulse-chase. $(A)$ Confluent fibroblasts were pulse-labeled for $1 \mathrm{~h}$, and then washed and incubated for varying time (chase) periods in medium containing $\sim 1,000$-fold excess of unlabeled methionine. At various time points ranging from 30 to $240 \mathrm{~min}, \mathrm{Cl} \mathrm{INH}$ proteins in intracellular lysates and extracellular media were analyzed as described in the legend for Fig. 1. ( $B$ and $C$ ) Incorporation of $\left[{ }^{35} \mathrm{~S}\right]$ methionine into individually immunoprecipitated wild type proteins in the intracellular lysates $(B)$ and extracellular media $(C)$ from normal (closed symbols) and HANE $\Delta_{\mathrm{Ex} 7}$ (open symbols) cells was determined as described in the Methocis. The results represent the mean \pm SD for three experiments.

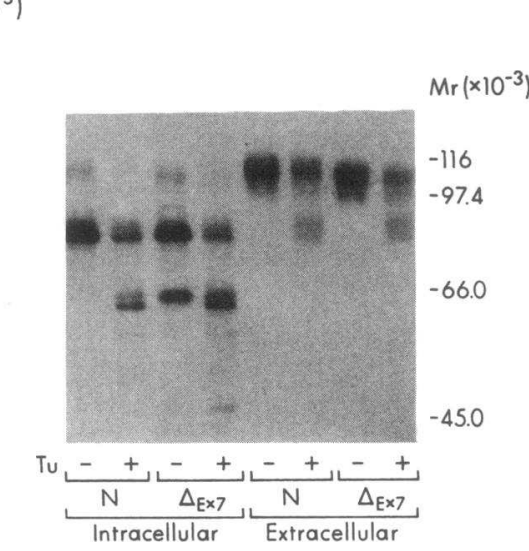

Figure 3. Effect of tunicamycin on molecular masses of $\mathrm{Cl}$ INH proteins synthesized and secreted from normal and HANE $\Delta_{\mathrm{Ex} 7}$ fibroblasts. Newly synthesized $\mathrm{Cl}$ INH proteins were radiolabeled with $\left[{ }^{35} \mathrm{~S}\right]$ methionine as described in the legend for Fig. 1. For the lanes indicated, tunicamycin (Tu), $5 \mu \mathrm{g} / \mathrm{ml}$, was present during the labeling period.

Analysis of CI INH mRNA suggests that regulation of synthesis of the wild type CI INH protein in HANE $\Delta_{E x>}$ occurs at the level of translation. Normal cells contain a single $\mathrm{C} 1 \mathrm{INH}$ mRNA species of $2.1 \mathrm{~kb}$, while HANE $\Delta_{\mathrm{Ex} 7}$ cells contain two C1 INH mRNA species (2.1 and $1.9 \mathrm{~kb}$ ) (Fig. 4). The content of the wild type $(2.1 \mathrm{~kb}) \mathrm{Cl}$ INH mRNA in the HANE $\Delta_{\mathrm{Ex} 7}$ cells was $52 \pm 2 \%(n=5)$ of normal, similar to the amount expected from a single allele. The contrast between the level of mRNA ( $52 \%$ of normal) and rate of protein synthesis ( $11 \%$ of normal) suggests that the decreased rate of synthesis of wild type $\mathrm{Cl}$ INH protein in the HANE $\Delta_{\mathrm{Ex} 7}$ cells is caused by a specific deficit in translation of the wild type $\mathrm{C} 1 \mathrm{INH}$ mRNA.

Unlike the wild type mRNA, the content of the mutant (1.9 kb) Cl INH mRNA was $17 \pm 1 \%(n=5)$ of normal. Factor B $(2.6 \mathrm{~kb})$ and $\mathrm{C} 3(5.1 \mathrm{~kb})$ mRNA content was equal in normal and HANE $\Delta_{\mathrm{Ex} 7}$ cells, indicating that the reduction in $\mathrm{C} 1 \mathrm{INH}$ mutant mRNA is specific. Inhibition of transcription with actinomycin D and timed measurement of levels of the $\mathrm{C} 1 \mathrm{INH}$ mRNAs in HANE $\Delta_{\mathrm{Ex} 7}$ and normal cells indicate that catabolism of the wild type and mutant mRNAs is similar (Fig. 5).

Expression of wild type C1 INH protein in HANE $\Delta_{E x>}$ is unique amongst HANE variants. C1 INH mRNA levels and synthesis rates of mutant and wild type $\mathrm{Cl}$ INH proteins in HANE $\Delta_{\mathrm{Ex} 7}$ cells were compared to the findings in type II and

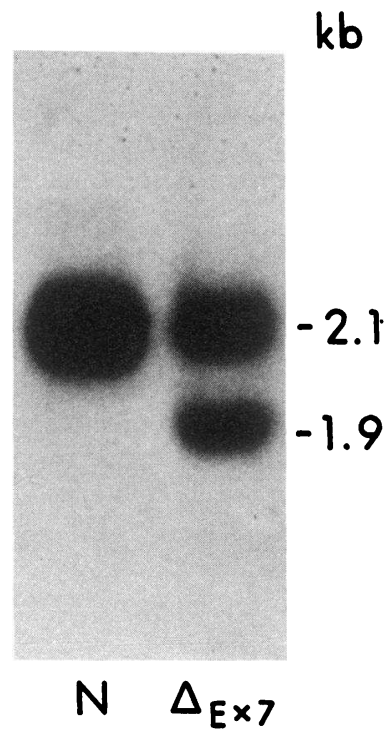

Figure 4. C1 INH mRNA content in normal and HANE $\Delta_{\mathrm{Ex} 7}$ fibroblasts. Fibroblasts were grown to confluence and total cellular RNA was extracted by lysis with guanidinium isothiocyanate and isolated by cesium chloride density gradient ultracentrifugation. Equal amounts $(10 \mu \mathrm{g})$ were electrophoresed on agarose-formaldehyde and transferred to nitrocellulose filters (Bio-Rad Laboratories, Richmond, CA) for RNA blot analysis using a riboprobe for $\mathrm{Cl}$ INH labeled with ${ }^{32} \mathrm{P}$. 


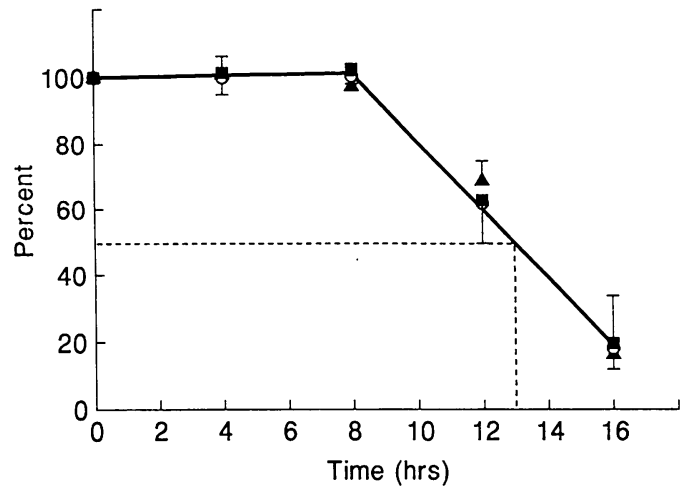

Figure 5. Catabolism of C1 INH mRNAs in normal and HANE $\Delta_{\mathrm{Ex} 7}$ fibroblasts. Replicate cultures of fibroblasts were washed and the medium was replaced with fresh medium containing actinomycin $D, 10$ $\mu \mathrm{g} / \mathrm{ml}$. After periods ranging up to $16 \mathrm{~h}$, the RNA was extracted as described in the legend for Fig. 4, and $10 \mu \mathrm{g}$ from each time point was subjected to RNA blot analysis. C1 INH mRNA was quantitated by scanning autoradiograms with soft laser densitometry. The densities of the specific signals were compared to the density of the signal before addition of actinomycin D. The data are represented as mean $\pm \mathrm{SD}$ for three experiments. The one-half time of disappearance of the three mRNA species, wild type in normal fibroblasts (squares), wild type in HANE $\Delta_{\mathrm{Ex} 7}$ fibroblasts (open circles), and mutant in HANE $\Delta_{\mathrm{Ex} 7}$ fibroblasts (triangles), were similar, each $\sim 5 \mathrm{~h}$.

other type I HANE patients (Table I). Fibroblasts from four unrelated patients with type I HANE contained $\mathrm{Cl}$ INH mRNA at $27 \%$ of normal and synthesized $\mathrm{C} 1 \mathrm{INH}$ protein at $20 \%$ of normal. In contrast to the findings in these type I patients, three patients with type II HANE contained $\mathrm{Cl}$ INH mRNA at $122 \%$ of normal, and synthesized wild type and mutant $\mathrm{C} 1 \mathrm{INH}$ proteins at 43 and $57 \%$ of normal, respectively. HANE $\Delta_{\mathrm{Ex} 7}$ is the only variant studied for which synthesis of $\mathrm{Cl}$ INH is less than predicted from the content of corresponding C1 INH mRNA. In HANE $\Delta_{\mathrm{Ex} 7}$, decreased synthesis relative to mRNA content occurs for both wild type and mutant $\mathrm{C} 1 \mathrm{INH}$ proteins.

\section{Discussion}

In most type I HANE kindred, the mutant allele and its primary transcript and protein product cannot be distinguished from the wild type forms (8). Recognition of type I HANE kindred in which one of several restriction length fragment polymorphisms is present allows the mutant allele to be identified separately from the wild type (15). For one of these kindred, HANE $\Delta_{\mathrm{Ex} 7}$, Cicardi et al. reported the presence of a mutant $\Delta_{\mathrm{Ex} 7} \mathrm{mRNA}$ in addition to the normal transcript in peripheral blood monocytes (9). We report that fibroblasts from a patient from this kindred contain this mutant mRNA, and they also synthesize a mutant protein of the molecular mass predicted from the structure of the mutant mRNA. $\Delta_{\mathrm{Ex} 7}$ yields type I HANE because the amount of wild type $\mathrm{Cl}$ INH protein synthesized is much less than the $50 \%$ expected from the single normal allele, similar to the findings of amounts of C1 INH protein synthesized in other type I HANE cells ( 8$)$. In HANE $\Delta_{\mathrm{Ex} 7}$, the net amount of wild type $\mathrm{C} 1 \mathrm{INH}$ protein synthesized was approximately fivefold less than the amount that would have been predicted from the wild type mRNA content
(Table I). Synthesis of less wild type protein than predicted could be caused by either a decreased rate of wild type $\mathrm{Cl}$ INH translation and/or increased rate of wild type protein catabolism in HANE $\Delta_{\mathrm{Ex} 7}$ cells. Since the intracellular catabolism of the wild type protein was not measurably increased, these data suggest that translation of the wild type mRNA in HANE $\Delta_{\mathrm{Ex} 7}$ cells is inhibited by a transeffect of either mutant mRNA or protein. Inhibition of translation by protein product has been proposed as a mechanism for regulating synthesis of type I procollagen and thymidylate synthase $(1,2)$. The decreased synthesis of wild type $\mathrm{C} 1 \mathrm{INH}$ protein in the HANE $\Delta_{\mathrm{Ex} 7}$ cells represents the first example of transinhibition of translation of a normal gene product by the products of a mutant allele. It should also be noted that inhibition of translation of the mutant C1 INH mRNA was also observed.

In addition to the markedly decreased rate of synthesis of wild type protein that yields type I HANE in $\Delta_{\mathrm{Ex} 7}$, the mutant protein is not present outside the cells. The rate of disappearance of the mutant protein from the HANE $\Delta_{\mathrm{Ex} 7}$ cells was similar to disappearance of the wild type protein, but no evidence for secretion was obtained. The possibility that the truncated protein is secreted but unstable in the extracellular medium cannot be eliminated.

The level of mutant mRNA in HANE $\Delta_{\mathrm{Ex} 7}$ cells is decreased below the $50 \%$ expected for the product of a single allele. Since the catabolism of this mRNA in the cytoplasm is normal, the reduced steady state mutant mRNA content is probably caused by either decreased transcription or intranuclear degradation of mutant $\mathrm{Cl}$ INH heteronuclear RNA.

HANE $\Delta_{\mathrm{Ex} 7}$ is unique amongst HANE variants studied ( $\mathrm{Ta}$ ble I). HANE $\Delta_{\mathrm{Ex} 7}$ is the only one in which the rate of wild type

Table I. Comparisons of $m R N A$ and Protein Synthesis Data in Variants of Hereditary Angioneurotic Edema

\begin{tabular}{|c|c|c|c|c|}
\hline & $\mathrm{N}$ & Gene & mRNA & Protein \\
\hline & & & $\%$ normal & $\%$ normal \\
\hline Normal & 6 & $\begin{array}{l}\text { W } \\
\text { W }\end{array}$ & $100^{*}$ & $100 \pm 43^{\ddagger} 5$ \\
\hline Type I $\Delta_{\mathrm{Ex} 7^{\S}}^{\S}$ & 1 & $\begin{array}{l}\mathrm{W} \\
\mathrm{M}\end{array}$ & $\begin{array}{l}51 \pm 2 \\
17 \pm 1\end{array}$ & $\begin{array}{r}11 \pm 3 \\
3 \pm 1\end{array}$ \\
\hline Type III & 4 & $\begin{array}{l}\mathrm{W} \\
\mathrm{M}\end{array}$ & $27 \pm 6^{9}$ & $20 \pm 9^{1}$ \\
\hline Type II" & 3 & $\begin{array}{l}\mathrm{W} \\
\mathrm{M}\end{array}$ & $122 \pm 33^{* *}$ & $\begin{array}{l}43 \pm 4 \\
57 \pm 8\end{array}$ \\
\hline
\end{tabular}

$\mathrm{N}$, number of fibroblast cell lines studied. * For mRNA studies, RNA from a single normal fibroblast line, GM8399 (Human Genetic Mutant Cells, National Institute of General Medical Sciences), was included on each RNA blot. For quantitation, density of the normal signal on each blot was defined as $100 \%$. ${ }^{\ddagger}$ Specific protein synthesis was determined as described in the legends for Figs. 1 and 2, $B$ and $C$, and in reference 8 . ${ }^{\S}$ Values are mean \pm SD for five experiments for RNA and six experiments for protein synthesis. "Data from previous studies with fibroblast lines developed from four patients with type I and three patients with type II HANE (8). 'For the typical type I cells, products of the mutant allele, if present, could not be distinguished from normal either structurally or immunochemically. ${ }^{* *}$ For the type II cells, structural differences in the mRNAs for the two alleles were not detected using Northern blot analysis. 
C1 INH protein synthesis ( $11 \%$ of normal) is markedly less than the level of wild type C1 INH mRNA ( $51 \%$ of normal). Hence, the structure of the $\Delta_{\mathrm{Ex} 7} \mathrm{mRNA}$ and/or protein is specific in its capacity to inhibit translation of $\mathrm{Cl}$ INH. In the four other HANE type I variants studied, only single species of $\mathrm{Cl}$ INH mRNA and protein could be identified. The similarities in reductions of mRNA content and protein synthesis indicate that $\mathrm{Cl}$ INH synthesis in these cells is reduced by alterations in mRNA content that occur before translation. Preliminary data indicate that the stability of $\mathrm{Cl}$ INH mRNA in these HANE type I variants is similar to normal, suggesting that regulation occurs during transcription or during processing of RNA in the nucleus. In the HANE type II variants studied, products of the wild type and mutant genes can be distinguished, similar to the situation in HANE $\Delta_{\mathrm{Ex} 7}$. However, unlike HANE $\Delta_{\mathrm{Ex} 7}$, type II HANE cells contain approximately the expected amount of $\mathrm{CI}$ INH mRNA and synthesize $\sim 50 \%$ of normal amounts of each of the wild type and mutant proteins (8). Also unlike HANE $\Delta_{\mathrm{Ex} 7}$, the mutant protein synthesized in type II cells is secreted normally and is stable in extracellular medium (8), where abnormalities in structures of the mutant proteins alter function without appreciably affecting mass (16). The $\Delta_{\mathrm{Ex} 7} \mathrm{mRNA}$ and protein have substantial differences from normal in molecular mass and probably in tertiary structure. Which of these or other abnormalities result in the differences for the processing and molecular regulation between normal (or type II HANE) and the HANE $\Delta_{\mathrm{Ex} 7}$ is not known.

Analysis of the mechanism of the transinhibition of wild type protein synthesis that occurs in HANE $\Delta_{\mathrm{Ex} 7}$ should provide important information about regulation of protein synthesis in other genetic deficiencies, as well as translation of mRNA in normal cells.

\section{Acknowledgments}

This work was supported by a grant from the March of Dimes (6-562), and National Institutes of Health grants DK-26609, HL-37591, and Al-24836.

\section{References}

1. Fouser, L., E. H. Sage, J. Clark, and P. Bornstein. 1991. Feedback regulation of collagen gene expression: a Trojan horse approach. Proc. Natl. Acad. Sci. USA. 88:10158-10162.

2. Chu, E., D. M. Koeller, J. L. Casey, J. C. Drake, B. A. Chabner, P. C. Elwood, S. Zinn, and C. J. Allegra. 1991. Autoregulation of human thymidylate synthase messenger RNA translation by thymidylate synthase. Proc. Natl. Acad. Sci. USA. 88:8977-8981.

3. Kazazian, H. H., and C. D. Boehm. 1988. Molecular basis and prenatal diagnosis of $\beta$-thalassemia. Blood. 72:1107-1116.

4. Davis, A. E. 1988. C1 inhibitor and hereditary angioneurotic edema. Annu. Rev. Immunol. 6:595-628.

5. Rosen, F. S., C. A. Alper, J. Pensky, M. R. Klemperer, and V. H. Donaldson. 1971. Genetically determined heterogeneity of the $\mathrm{Cl}$ esterase inhibitor in patients with hereditary angioneurotic edema. J. Clin. Invest. 50:2143-2149.

6. Quastel, M., R. Harrison, M. Cicardi, C. A. Alper, and F. S. Rosen. 1983. Behavior in vivo of normal and dysfunctional $\mathrm{Cl}$ inhibitor in normal subjects and patients with hereditary angioneurotic edema. J. Clin. Invest. 71:1041-1046.

7. Lachmann, P. J., and F. S. Rosen. 1984. The catabolism of C1-inhibitor and the pathogenesis of hereditary angio-edema. Acta Pathol. Microbiol. Immunol. Scand. 92:35-39.

8. Kramer, J., Y. Katz, F. S. Rosen, A. E. Davis, and R. C. Strunk. 1991. Synthesis of $\mathrm{Cl}$ inhibitor in fibroblasts from patients with type I and type II hereditary angioneurotic edema. J. Clin. Invest. 87:1614-1620.

9. Cicardi, M., T. Igarashi, F. S. Rosen, and A. E. Davis. 1987. Molecular basis for the deficiency of complement 1 inhibitor in type I hereditary angioneurotic edema. J. Clin. Invest. 79:698-702.

10. Ariga, T., T. Igarashi, N. Ramesh, R. Parad, M. Cicardi, and A. E. Davis. 1989. Type I Cl inhibitor deficiency with a small messenger RNA resulting from deletion of one exon. J. Clin. Invest. 83:1888-1893.

11. Ariga, T., P. E. Carter, and A. E. Davis. 1990. Recombinations between Alu repeat sequences that result in partial deletions within the $\mathrm{Cl}$ inhibitor gene. Genomics. 8:607-613.

12. Parad, R. B., J. Kramer, R. C. Strunk, F. S. Rosen, and A. E. Davis. 1990. Dysfunctional $\mathrm{C} 1$ inhibitor Ta: deletion of lys-251 results in acquisition of an $N$-glycosylation site. Proc. Natl. Acad. Sci. USA. 87:6786-6790.

13. Davis, A. D., K. Aulak, R. B. Parad, H. P. Stecklein, E. Eldering, C. E. Hack, J. Kramer, R. C. Strunk, J. Bissler, and F. S. Rosen. 1992. C1 inhibitor hinge region mutations ( $\mathrm{P} 10 \mathrm{Ala}$ to $\mathrm{Thr}$ and $\mathrm{P} 14 \mathrm{Val}$ to $\mathrm{Glu}$ ) produce dysfunction by different mechanisms. Nat. Genet. In press.

14. Cole, F. S., H. S. Auerbach, G. Goldberger, and H. R. Colten. 1985. Tissue-specific pretranslational regulation of complement production in human mononuclear phagocytes. J. Immunol. 134:2610-2616.

15. Stoppa-Lyonnet, D., C. Duponchel, T. Meo, J. Laurent, P. E. Carter, M. Arala-Chaves, J. H. M. Cohen, G. Dewald, J. Goetz, G. Hauptmann, et al. 1991. Recombinational biases in the rearranged $\mathrm{Cl}$-inhibitor genes of hereditary angioedema patients. Am. J. Hum. Genet. 49:1055-1062.

16. Donaldson, V. H., R. A. Harrison, F. S. Rosen, D. H. Bing, G. Kindness, J. Canar, C. J. Wagner, and S. Awad. 1985. Variability in purified dysfunctional $\mathrm{Cl}$-inhibitor proteins from patients with hereditary angioneurotic edema. Functional and analytical get studies. J. Clin. Invest. 75:124-132. 